19 Revue d'histoire du XIXe siècle

Société d'histoire de la révolution de 1848 et des

révolutions du XIXe siècle

$37 \mid 2008$

L'ère victorienne revisitée

\title{
Maurice LACHÂTRE, Cinq centimes par jour. Méthodes commerciales d'un éditeur engagé
}

Jean-Claude Caron

\section{OpenEdition}

\section{Journals}

Édition électronique

URL : http://journals.openedition.org/rh19/3537

DOl : $10.4000 /$ rh 19.3537

ISSN : $1777-5329$

Éditeur

La Société de 1848

Édition imprimée

Date de publication : 15 novembre 2008

Pagination : 185-242

ISSN : 1265-1354

Référence électronique

Jean-Claude Caron, "Maurice LACHÂTRE, Cinq centimes par jour. Méthodes commerciales d'un éditeur engagé », Revue d'histoire du XIXe siècle [En ligne], 37 | 2008, mis en ligne le 01 décembre 2008, consulté le 22 septembre 2020. URL : http://journals.openedition.org/rh19/3537 ; DOI : https:// doi.org/10.4000/rh19.3537

Ce document a été généré automatiquement le 22 septembre 2020.

Tous droits réservés 


\title{
Maurice LACHÂTRE, Cinq centimes par jour. Méthodes commerciales d'un éditeur engagé
}

\author{
Jean-Claude Caron
}

\section{RÉFÉRENCE}

Maurice LACHÂTRE, Cinq centimes par jour. Méthodes commerciales d'un éditeur engagé , présentation de François Gaudin et Jean-Yves Mollier, Mont-Saint-Aignan, Publications des Universités de Rouen et du Havre, 2008, 87 p. ISBN : 978-2-87775-441-5. 10 euros.

1 Ce petit volume contient deux textes de 1866 du lexicographe, libraire et éditeur Maurice Lachâtre (1814-1900): Conseils aux courtiers en librairie et Instructions sur l'organisation des Docks du commerce et de la librairie. Dans leur introduction, François Gaudin (qui a soutenu une thèse sur Maurice Lachâtre) et Jean-Yves Mollier (son directeur de thèse) retracent la carrière d'un homme engagé à gauche, au risque de l'exil - par deux fois : sous le Second Empire et au lendemain de la Commune -, mais qui cultiva des réseaux très variés. Cela lui permit d'éditer, parmi ses contemporains, Alexandre Dumas, Louis Napoléon Bonaparte, Louis Blanc, Eugène Sue et Karl Marx dont il publia la première traduction française du Capital. Mais ce sont surtout les nombreux dictionnaires qu'il met en chantier qui assurent ses revenus. Et qui le mettent en relation avec toutes les "plumes » de Paris, en quête de quelque revenu Michelet ne dédaigne pas collaborer à ses œuvres lexicographiques. Au meilleur sens $\mathrm{du}$ terme, Maurice Lachâtre est un éditeur qui entend participer à l'éducation du peuple par la vulgarisation des idées auxquelles il croit. Proche de Félix Pyat, intéressé par le fouriérisme (il édite Zoé Gatti de Gamond), admirateur de Proudhon, adepte du spiritisme, Maurice Lachâtre adhère finalement à l'anarchisme fin de siècle, celui de Jean Grave. Si les deux textes proposés ici ont une couleur professionnelle très marquée, émanant de quelqu'un qui connaît toute la filière de production de l'imprimé, 
ils ne sont pas pour autant dénués d'une intention morale, sociale, voire politique. On peut certes s'interroger sur les positions de quelqu'un qui, devenu en bonne partie par héritage le «baron rouge " (il possède plusieurs propriétés, dont les Jardies racheté à Balzac, et des vignes dans le bordelais), prône à ses futurs courtiers la restitution de leurs biens au fonds commun... On reste frappé par la mobilité constante de l'homme, parfois contrainte, et par sa capacité d'entrepreneur qui, confronté à l'échec, n'en relance pas moins en permanence des "affaires ». Mais ce dynamisme entrepreneurial ne le détourne pas pour autant des idéaux qu'il défend. Et c'est bien l'esprit du siècle qui transparaît ici, entre coopération et égalitarisme, faisant de Maurice Lachâtre, selon François Gaudin et Jean-Yves Mollier, un précurseur de François Maspero et de la Joie de Lire. 